\title{
Порівняльна характеристика функціональних можливостей та фізичної працездатності чоловіків і жінок, які спеціалізуються в бігу на середні дистанції
}

\author{
УДК 796.422.14-055.1/.2
}

\author{
О. Б. Рода, С. В. Калитка, і. М. Войтович
}

Східноєвропейський національний університет імені Лесі Українки, Луцьк, Україна

\begin{abstract}
Резюме. Мета. Вивчити динаміку функціональних можливостей та фізичної працездатності кваліфікованих спортсменів, які спеціалізуються у легкоатлетичному бігу на середні дистанції. Методи. Анкетування, педагогічний експеримент, медико-біологічні та методи математичної статистики. В обстеженні взяли участь 13 жінок та 10 чоловіків, які спеціалізуються в бігу на середні дистанції, віком 17-24 роки, які мали кваліфікацію I та II розрядів і кандидата в майстри спорту. Результати. Установлено, що функціональний стан і фізична працездатність упродовж мезоциклу у жінок залежать від зміни гормонального статусу протягом менструального циклу; у чоловіків - поступово зростають до настання втоми. Найвищі показники фізичної працездатності та функціонального стану у спортсменок було зафіксовано в постменструальну $(p<0,05)$ та постовуляторну фази $(p<0,05)$; вони значно знижуються в овуляторну ( $<<0,05)$, передменструальну та менструальну фази $(p<0,05)$. Показники фізичної працездатності та функціонального стану у чоловіків-спортсменів І розряду та КМС зростали у першому, другому, найвищими були у третьому, знизилися в четвертому і найменшими були у п'ятому мікроциклах ( $<<0,05)$; у спортсменів II розряду найменший рівень відзначали в першому, зростання - у другому, третьому і четвертому мікроциклах та найбільший - у п'ятому. Висновки. Результати взаємозв'язку рівня прояву функціональних можливостей спортсменів і ефективності виконання специфічних навантажень мезоциклу стали методологічною основою розробки програм їх спортивної підготовки.
\end{abstract}

Ключові слова: фізична працездатність, біг на середні дистанції, адаптація, функціональний стан, чоловіки, жінки.

\section{Сравнительная характеристика функциональных возможностей и физической работоспособности мужчин и женщин, специализирующихся в беге на средние дистанции \\ О. Б. Рода, С. В. Калитка, И. Н. Войтович}

Восточноевропейский национальный университет имени Леси Украинки, Луцк, Украина

Резюме. Цель. Изучить динамику функциональных возможностей и физической работоспособности квалифицированных спортсменов, специализирующихся в легкоатлетическом беге на средние дистанции. Методы. Анкетирование, педагогический эксперимент, медико-биологические и методы математической статистики. В обследовании приняли участие 13 женщин и 10 мужчин, специализирующихся в беге на средние дистанции в возрасте 17-24 года, которые имели квалификацию I и II разрядов и кандидата в мастера спорта. Результаты. Установлено, что функциональное состояние и физическая работоспособность в течение мезоцикла у женщин зависят от изменения гормонального статуса в течение менструального цикла; у мужчин - постепенно возрастают до наступления усталости. Наивысшие показатели физической работоспособности и функционального состояния у спортсменок были зафиксированы в постменструальную $(\mathrm{p}<0,05)$ и постовуляторную $(p<0,05)$ фазы, значительно снижаются в овуляторную $(p<0,05)$, предменструальную и менструальную фазы $(\mathrm{p}<0,05)$. Показатели физической 
работоспособности и функционального состояния у мужчин-спортсменов I разряда и KMC возросли в первом, втором, наивысшими были в третьем, снизились в четвертом и наименьшими были в пятом микроциклах ( $<0,05)$; у спортсменов II разряда наименьший уровень отмечали в первом, возрастание - во втором, третьем и четвертом микроциклах и наибольший - в пятом. Выводы. Результаты взаимосвязи уровня проявления функциональных возможностей спортсменов и эффективности выполнения специфических нагрузок мезоцикла стали методологической основой разработки программ их спортивной подготовки.

Ключевые слова: физическая работоспособность, бег на средние дистанции, адаптация, функциональное состояние, мужчины, женщины.

\title{
Comparative characteristic of functional capabilities and physical performance of men and women specializing in middle-distance running
}

\section{O. B. Roda, S. V. Kalytka, I. M. Voytovych}

Lesya Ukrainka Eastern European National University, Lutsk, Ukraine

\begin{abstract}
Aim. To study the dynamics of functional capabilities and physical performance of qualified athletes specializing in middle-distance running. Methods. Questionnaire, pedagogical experiment, biomedical and mathematical statistics methods. The survey involved 13 women and 10 men at the age of 17-24 specializing in middle-distance running who has qualified as First-andSecond-Class Candidates for Master of Sport. Results. It has been determined that the women functional status and physical capacity during the mesocycle depend on the hormonal status changes during the menstrual cycle; in men - gradually increasing before the onset of fatigue. The highest rates of physical performance and functional capabilities among women athletes were recorded in the postmenstrual $(p<0.05)$ and postovulatory phases $(p<0.05)$; decrease significantly in ovulatory $(p<0.05)$, premenstrual and menstrual phases $(p<0.05)$. Indices of men physical performance and functional capabilities of the Candidates for Master of Sport and FirstClass Sportsmans were increasing in the first, second, were highest in the third, were decreased in the fourth and were the lowest in the fifth microcycle $(p<0.05)$; Second-Class Sportsmans have the lowest level in the first, growth in the second, third and fourth levels and the highest in the fifth level microcycles. Conclusions. The results of the correlation between the level of manifestation of the functional capabilities of athletes and the performance of the mesocycle specific loads became the methodological basis for the development of their sports training programs.
\end{abstract}

Keywords: physical performance, middle-distance running, adaptation, functional status, men, women.

Вступ. Сучасний спорт характеризується неухильним зростанням спортивних досягнень, що супроводжується збільшенням обсягів та інтенсивності тренувального навантаження. Такий підхід до тренувального процесу часто призводить до перенапруження регуляторних систем, виснаження адаптаційного резерву та скорочення термінів виступів спортсменів, що не дає змоги досягти високих спортивних результатів. Дедалі більшого значення набуває питання оптимальної побудови й удосконалення тренувального процесу спортсменів з урахуванням їхнього фрункціонального стану. Вивченню цих питань присвячено значну кількість досліджень $[2,4,5]$.

На сьогодні спортивна підготовка жінок здійснюється за програмою підготовки чоловіків. Однак діяльність функціональних систем, адаптаційні процеси в організмі жінок відрізняються від таких у чоловіків. Це обумовлено однією з основних біологічних особливостей жіночого організму, пов'язаних з репродуктивною функ- цією, що супроводжується значними періодичними перебудовами гормонального статусу, обумовлюючи різні фуннціональні можливості, зміни загальної та спеціальної працездатності в різні фрази менструального циклу. Низку досліджень присвячено вивченню впливу статевих гормонів на фуункціональний стан, адаптаційні реакції та прояв фрізичних якостей у системі спортивної підготовки жінок [3, 6-9].

Проблема підвищення ефективності тренувальної роботи спортсменок відповідно до функціонального стану у різні фрази менструального циклу (МЦ), а також реакції адаптаційних механізмів на специсрічні навантаження, підготовленості і відповідно різної побудови тренувальних мезоциклів жінок і чоловіків, які спеціалізуються в бігу на середні дистанції, залишається недостатньо вивченою. Цим обумовлена актуальність нашого дослідження.

Мета дослідження - вивчити динаміку функціональних можливостей та фрізичної працездат- 
ності кваліфікованих спортсменів, які спеціалізуються у легкоатлетичному бігу на середні дистанції.

Методи й організація дослідження. Аналіз й узагальнення наукової та методичної літератури; анкетування; педагогічне спостереження; педагогічний експеримент; медико-біологічні та методи математичної статистики.

Для визначення фрункціонального стану серцево-судинної системи перед тренуванням у стані відносного спокою визначали варіабельність серцевого ритму. Показники спектрального аналізу варіабельності серцевого ритму (ВСР) установлювали за допомогою програми Поліспектр (Нейрософт, Росія). Використовували такі показники кардіоінтервалографії: М (математичне очікування) - показник, який відображає кінцевий результат усіх регуляторних впливів на серце і кровообіг у цілому, він $\epsilon$ еквівалентом середньої ЧСС; Мо (мода) - значення RR-інтервалу, які трапляються найчастіше; AMо (амплітуда моди) - відсоток кардіоінтервалів RR, що відповідає значенню моди; ВР (варіаційний розмах) - різниця між тривалістю найбільшого й найменшого RR-інтервалів. На їх основі розраховували індекси, запропоновані Р. М. Баєвським: IBP - індекс вегетативної рівноваги (IBP = AMo / ВР); ПАПР - показник адекватності процесів регуляції (ПАПР = АМо/Мо); ВПР - вегетативний показник ритму $(\mathrm{BПP}=1 /($ Мо $\cdot \mathrm{BP}))$; IH - індекс напруження регуляторних систем (IH $=\mathrm{AMo} /$ (2BP・ Мо)) [1, 4].

Рівень енергозабезпечення організму легкоатлетів оцінювали на основі виконання ними стандартного велоергометричного тесту $\mathrm{PWC}_{170}$ і розрахунку на базі отриманих даних усіх параметрів фрункціональної підготовленості за методикою та використанням формул. Мета застосування цього тесту - визначення аеробного компонента фрізичної працездатності спортсменів. Тест ступінчасто зростаючої потужності виконували на стаціонарному велоергометрі, тривалість педалювання - 9 хв. За цей час навантаження тесту зростало двічі (через 3 і 6 хв). ЧСС вимірювали протягом останніх 15 с кожного 3-хвилинного ступеня, а збільшення тестового навантаження регулювали таким чином, щоб ЧСС до кінця тесту збільшилася до 170 уд хв ${ }^{-1}$. Початкове навантаження становило 1,25 Вт на 1 кг маси обстежуваного. ЧСС реєстрували за допомогою стетоскопа, а розрахунок здійснювали за формулою:

$$
P W C_{170}=\frac{\frac{\left(W_{3}-W_{2}\right)}{\left(\Psi C C_{3}-\Psi C C_{2}\right)} \times\left(170-\Psi C C_{3}\right)+W_{3}}{m},
$$

де $W_{2}$ і $W_{3}$ - навантаження 2-го й 3-го ступенів

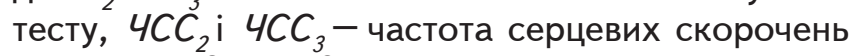
наприкінці 2-го й 3-го ступенів; $m$ - маса тіла.

Основні критерії адаптації в спортивному тренуванні - частота серцевих скорочень (ЧСС) та максимальне споживання кисню ( $\left.\dot{\mathrm{V}}_{2} \mathrm{max}\right)$, які відображають максимальну аеробну потужність організму. Для розрахунку VO $_{2}$ max спортсменів, які тренуються на витривалість, застосовували фрормулу:

$$
\dot{\mathrm{VO}}_{2} \max =2,2 \mathrm{PWC}_{170}+1070 .
$$

У дослідженні взяли участь 13 жінок та 10 чоловіків, які спеціалізуються в бігу на середні дистанції, віком 17-24 роки, які мали кваліфрікацію I та II розрядів і кандидата в майстри спорту. Стан здоров'я всіх спортсменів був у межах фрізіологічної норми. Обстеження жінок проводили 3 урахуванням фаз менструального циклу, паралельно в той самий час обстежували чоловіків.

Результати дослідження та їх обговорення. Для визначення оптимальної побудови базових мезоциклів чоловіків і жінок, які спеціалізуються в бігу на середні дистанції, було проведено комплексне дослідження в мезоциклі планового тренувального процесу, що складався 3 п'яти ударних мікроциклів, які містили три заняття зі значними навантаженнями та були ідентичними за своєю побудовою. Обсяг та інтенсивність тренувального навантаження для кожного окремого спортсмена однакові та відповідали їх підготовленості та функціональним можливостям. Таку структуру мезоциклу було обрано для вивчення формування відтермінованого тренувального есректу.

Першого, третього та п'ятого дня мікроциклу застосовували тренувальні засоби, які переважно розвивають швидкість та анаеробно-аеробні можливості. Другого, четвертого та шостого дня застосовували засоби для розвитку витривалості та аеробних можливостей, швидкості та сили. Сьомий день був відведений для відпочинку й відновлення (табл. 1).

Визначаючи ступінь адаптації серцево-судинної системи до різних фракторів й оцінку адекватності процесів регуляції, ми використовували запропоновані Р. М. Баєвським (2001) індекси (табл. 2). Установлено, що найвищі показники IBP, ПАПР, ВПР та IH було виявлено в V фразу, їхнє зниження спостерігалося в I, II та III фрази. Вірогідно нижчі показники зафріксовано у IV фазу $(p<0,05)$, що свідчить про зниження впливу симпатичної системи на ритм серця, а отже, зниження ступеня напруженості регуляторних систем і підвищення функціональних 
можливостей серцево-судинної системи спортсменок у ці фрази порівняно із V.

Визначено, що в чоловіків вищі показники IBP, ПАПР, ВПР та IH були в перший, четвертий та вірогідно вищі у другий ( $<<0,01, \mathrm{p}<0,05$ ) мікроцикли і значно нижчі - у третій та п'ятий мікроцикли, що свідчить про зниження симпатичних впливів на ритм серця і зменшення ступеня

ТАБЛИЦЯ 1 - Ударний мікроцикл для легкоатлетів, які спеціалізуються в бігу на середні дистанції

\begin{tabular}{|c|c|}
\hline $\begin{array}{c}\text { День } \\
\text { мікроциклу }\end{array}$ & Засоби \\
\hline Перший & $\begin{array}{l}\text { Розминка: біг 3-6 км, загальнорозвиваючі вправи. Прискорення 6×100 м - } 70 \text { \%. Їнтервальний біг на відрізках } \\
4 \times 400-600 \text { м - 85-90 \% максимальної, або перемінний біг на відрізках 6×200 м, 4×300 м зі швидкістю } 85 \text { \% мак- } \\
\text { симальної, або повторний біг 2×800 м чи 1×1500 м зі швидкістю 85-90 \% максимальної. Відпочинок до повного } \\
\text { відновлення. Комплекс стрибкових вправ. Повільний біг 2-3 км }\end{array}$ \\
\hline Другий & $\begin{array}{l}\text { Рівномірний крос 6-10 км. Загальнорозвиваючі вправи. Комплекс спеціальних вправ. Прискорення } 6 \times 100 \text { м - } \\
70 \text { \%. Комплекс силових вправ }\end{array}$ \\
\hline Третій & $\begin{array}{l}\text { Розминка: біг 3-6 км, загальнорозвиваючі вправи. Прискорення } 6 \times 100 \text { м - } 70 \text { \%. Їнтервальний біг на відрізках } \\
4 \times 400-600 \text { м - 85-90 \% максимальної, або перемінний біг на відрізках 6×200 м, 4×300 м зі швидкістю } 85 \text { \% мак- } \\
\text { симальної, або повторний біг 2×800 м чи 1×1500 м зі швидкістю 85-90 \% максимальної. Відпочинок до повного } \\
\text { відновлення. Комплекс стрибкових вправ. Повільний біг 2-3 км }\end{array}$ \\
\hline Четвертий & $\begin{array}{l}\text { Рівномірний крос 6-10 км. Загальнорозвиваючі вправи. Комплекс спеціальних вправ. Прискорення } 6 \times 100 \text { м - } \\
70 \text { \%. Комплекс силових вправ }\end{array}$ \\
\hline П'ятий & $\begin{array}{l}\text { Розминка: біг 3-6 км, загальнорозвиваючі вправи. Прискорення } 6 \times 100 \text { м - } 70 \text { \%. Їнтервальний біг на відрізках } \\
4 \times 400-600 \text { м - 85-90 \% максимальної, або перемінний біг на відрізках 6×200 м, 4×300 м зі швидкістю } 85 \text { \% мак- } \\
\text { симальної, або повторний біг 2×800 м чи 1×1500 м зі швидкістю 85-90 \% максимальної. Відпочинок до повного } \\
\text { відновлення. Комплекс стрибкових вправ. Повільний біг 2-3 км }\end{array}$ \\
\hline Шостий & $\begin{array}{l}\text { Рівномірний крос 8-10 км. Загальнорозвиваючі вправи. Комплекс спеціальних вправ. Прискорення } 6 \times 100 \text { м - } \\
70 \text { \%. Комплекс силових вправ }\end{array}$ \\
\hline Сьомий & Відпочинок \\
\hline
\end{tabular}

ТАБЛИЦЯ 2 - Показники кардіоінтервалографії жінок, які спеціалізуються в бігу на середні дистанції, за індексами Р. М. Баєвського у різні фази МЦ (фонова проба)

\begin{tabular}{|c|c|c|c|c|c|c|c|c|c|c|}
\hline \multirow{3}{*}{ Показники } & \multicolumn{10}{|c|}{ Фази Мц } \\
\hline & \multicolumn{2}{|r|}{ I } & \multicolumn{2}{|r|}{ II } & \multicolumn{2}{|r|}{ III } & \multicolumn{2}{|r|}{ IV } & \multicolumn{2}{|r|}{$\mathbf{v}$} \\
\hline & Медіана & $\begin{array}{c}25-75-и ̆ \\
\text { перцентиль }\end{array}$ & Медіана & $\begin{array}{c}25-75-и ̆ \\
\text { перцентиль }\end{array}$ & Медіана & $\begin{array}{c}25-75-и ̆ \\
\text { перцентиль }\end{array}$ & Медіана & $\begin{array}{c}25-75-и ̆ \\
\text { перцентиль }\end{array}$ & Медіана & $\begin{array}{c}25-75-\text { й } \\
\text { перцентиль }\end{array}$ \\
\hline İBP, y. o. & 155 & $105-225$ & 172 & $111-196$ & 145 & $104-192$ & $127^{\star}$ & $92,5-185$ & 224 & $117-306$ \\
\hline ПАПР, у. о. & 39,3 & $32,9-59,0$ & $39,6^{\star *}$ & $32,3-45,9$ & $39,1^{*}$ & $30,4-52,5$ & $39,4^{\star \star}$ & $30,3-43,9$ & 59,7 & $41,8-75,1$ \\
\hline ВПР, у. о. & 4,79 & 3,94-5,34 & 4,39 & $3,69-5,48$ & 4,17 & $3,28-5,70$ & 4,38 & $3,01-5,04$ & 5,74 & 3,21 \\
\hline İH, y. o. & 91,4 & $63,7-129,0$ & 90,6 & $53,1-105,0$ & 68,1 & $48,3-119,0$ & $66,5^{\star}$ & $52,4-107,0$ & 110,0 & $74,0-216,0$ \\
\hline
\end{tabular}

Примітка. Достовірні зміни результатів порівняно з передменструальною фразою МЦ: ${ }^{*}-p<0,05 ;{ }^{* *}-p<0,01$.

ТАБЛИЦЯ 3 - Показники кардіоінтервалографії варіабельності серцевого ритму спортсменів, які спеціалізуються в бігу на середні дистанції, за індексами Р. М. Баєвського у різні мікроцикли базового мезоциклу (фонова проба)

\begin{tabular}{|c|c|c|c|c|c|c|c|c|c|c|}
\hline \multirow{3}{*}{ Показники } & \multicolumn{10}{|c|}{ Мікроцикли } \\
\hline & \multicolumn{2}{|r|}{ I } & \multicolumn{2}{|r|}{ II } & \multicolumn{2}{|r|}{ III } & \multicolumn{2}{|r|}{ IV } & \multicolumn{2}{|r|}{$\mathbf{v}$} \\
\hline & Медіана & $\begin{array}{c}\text { 25-75-й } \\
\text { перцентиль }\end{array}$ & Медіана & $\begin{array}{c}\text { 25-75-й } \\
\text { перцентиль }\end{array}$ & Медіана & $\begin{array}{c}25-75-и ̆ \\
\text { перцентиль }\end{array}$ & Медіана & $\begin{array}{c}25-75-и ̆ \\
\text { перцентиль }\end{array}$ & Медіана & $\begin{array}{c}\text { 25-75-й } \\
\text { перцентиль }\end{array}$ \\
\hline İBP, y. o. & 106,0 & $69,1-387,0$ & $177,0^{\star \star}$ & $79,1-412,0$ & 63,75 & $47,4-193,0$ & 98,05 & $40,5-370,0$ & 83,65 & $36,8-338,0$ \\
\hline ПАПР, у. о. & 32,55 & $21,9-50,5$ & 33,85 & $25,3-79,3$ & 33,55 & $22,4-78,2$ & $45,95^{\star}$ & $30,3-83,9$ & 55,15 & $23,4-74,1$ \\
\hline ВПР, у. о. & 3,725 & $3,0-9,85$ & 4,135 & $3,17-13,80$ & 3,575 & $1,7-12,8$ & $6,895^{\star}$ & $3,1-11,4$ & 6,08 & $2,53-9,34$ \\
\hline İH, y. o. & 55,2 & $35,1-255,0$ & $80,4^{\star \star}$ & $37,6-336,0$ & 22,8 & $12,3-92,0$ & 51,4 & $18,4-266,0$ & 43,6 & $19,2-233,0$ \\
\hline
\end{tabular}

Примітка. Достовірні зміни результатів порівняно з III мікроциклом: ${ }^{*}-\mathrm{p}<0,05$;* $^{*}$ p $<0,01$. 
ТАБЛИЦЯ 4 - Показники фізичної працездатності жінок у різні фази МЦ

\begin{tabular}{|c|c|c|c|}
\hline \multirow[b]{2}{*}{$\begin{array}{c}\text { Фаза } \\
\text { МЦ }\end{array}$} & \multicolumn{3}{|c|}{ Показник } \\
\hline & маса тіла (кг) & $\begin{array}{c}\mathrm{PWC}_{170}\left(\text { (кгм } \cdot \mathbf{x B}^{-1}\right) \\
\text { (абсолютна } \\
\text { величина) }\end{array}$ & $\begin{array}{c}\mathrm{PWC}_{170} \\
\left(\mathrm{KrM}^{-1} \cdot \mathbf{X B}^{-1} \cdot \mathrm{Kr}^{-1}\right) \\
\text { (відносна величина) }\end{array}$ \\
\hline \multicolumn{4}{|c|}{ I розряд, КМС } \\
\hline I & $53,91 \pm 2,62$ & $1018,70 \pm 101,66$ & $18,97 \pm 2,39$ \\
\hline II & $53,84 \pm 2,50$ & $1033,12 \pm 184,06$ & $19,15 \pm 3,15$ \\
\hline III & $53,71 \pm 2,59$ & $1000,13 \pm 129,86$ & $18,62 \pm 2,37$ \\
\hline IV & $53,78 \pm 2,51$ & $1080,29 \pm 137,80$ & $20,06 \pm 2,06$ \\
\hline V & $54,19 \pm 2,63$ & $926,81 \pm 189,08$ & $17,14 \pm 3,52$ \\
\hline \multicolumn{4}{|c|}{ // розряд } \\
\hline I & $61,34 \pm 5,22$ & $947,56 \pm 275,75^{\circ}$ & $15,34 \pm 3,93^{\bullet}$ \\
\hline II & $61,32 \pm 5,18$ & $1065,81 \pm 308,48^{*} \cdot$ & $17,18 \pm 4,12^{* \bullet}$ \\
\hline III & $60,98 \pm 5,01$ & $957,43 \pm 267,80^{\bullet}$ & $15,53 \pm 3,41^{\bullet}$ \\
\hline IV & $60,98 \pm 4,94$ & $1221,85 \pm 245,83^{*}$ & $19,88 \pm 2,72^{*}$ \\
\hline V & $61,60 \pm 5,18$ & $921,12 \pm 197,48^{\bullet}$ & $14,84 \pm 2,43^{\circ}$ \\
\hline
\end{tabular}

Примітки. Достовірні зміни результатів: * - порівняно 3 передменструальною фразою МЦ ( $<<0,05)$;

- - порівняно 3 постовуляторною фразою МЦ ( $<<0,05)$.

напруженості регуляторних систем та підвищення функціональних можливостей серцево-судинної системи спортсменів у ці мікроцикли (табл. 3).

Одним з основних критеріїв адаптації в спортивному тренуванні $\epsilon$ частота серцевих скорочень (ЧСС) та максимальне споживання кисню ( $\left.\mathrm{VO}_{2} \max \right)$, які відображають максимальну аеробну потужність організму. Нами визначено, що динаміка прояву фізичної працездатності $\mathrm{PWC}_{170}$ у жінок має циклічний характер і залежить від змін гормонального статусу їх організму впродовж специфічного біологічного циклу. Найвищі показники фрізичної працездатності у спортсменок (I розряду та кандидатів у майстри спорту) було зафріксовано в II (постментструальну) та IV (постовуляторну) фрази порівняно із I (менструальною), III (овуляторною) та V (передменструальною). Вірогідно вищі показники фрізичної працездатності у спортсменок II розряду - упродовж II та IV фази $(p<0,05)$ порівняно 3 V фразою, та в I, III та $V$ фрази вірогідно нижчі показники $(p<0,05)$ порівняно з IV фазою. В усіх спортсменок визначено максимальне збільшення маси тіла в передменструальній фразі $(54,19 \pm 2,63$ кг (I розряд, KMC), 61,60 \pm 5,18 кг (II розряд)) (табл. 4) та незначні зміни маси тіла в I, II, III та IV фразах МЦ.

Працездатність спортсменів залежить від аеробних можливостей та споживання кисню працюючими м'язами. Отримані нами результати засвідчили, що найбільший показник $\mathrm{VO}_{2} \max$, а отже найвищий рівень функціональних можливостей серцево-судинної та дихальної систем, визначено у спортсменок I розряду і КМС (рис. 1) у постовуляторній фразі, дещо нижчий рівень $\dot{V}_{2} \max$ - у менструальній, постменструальній фазах МЦ та значно нижчі - в овуляторній та передменструальній.

Таку саму тенденцію виявлено в легкоатлеток із другим розрядом (рис. 2), вірогідно вищий показник у постовуляторній фразі $(p<0,05)$ порівняно $з$ передменструальною, і вірогідно нижчий показник - у постменструальній фразі $(p<0,05)$ порівняно $з$ передменструальною та постовуляторною фазами МЦ.

У менструальній та овуляторній фразах МЦ виявлено вірогідно нижчі показники ( $<0,05)$ порівняно $з$ постовуляторною, і найнижчий показник - у передменструальній фразі МЦ.

Порівнюючи значення $\mathrm{PWC}_{170}$ та $\mathrm{VO}_{2} \max$, бачимо, що динаміка прояву фрізичної працездатності в жінок має циклічний характер і залежить від змін впливу гормонального статусу на їхній організм протягом МЦ. Це впливає на коливання маси тіла, рівень працездатності, аеробних можливостей та стан кардіореспіраторної системи.

Показники фрізичної працездатності (відносної величини) $\mathrm{PWC}_{170}$ у чоловіків-спортсменів I розряду та кандидатів у майстри спорту мали тенденцію до поступового зростання протягом пер-

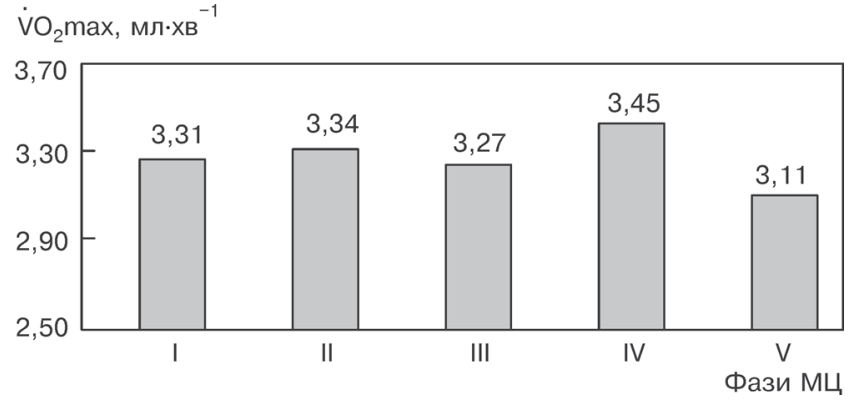

Рисунок 1 - Динаміка максимального споживання кисню у жінок-спортсменок у різні фази МЦ (І розряд, КМС)

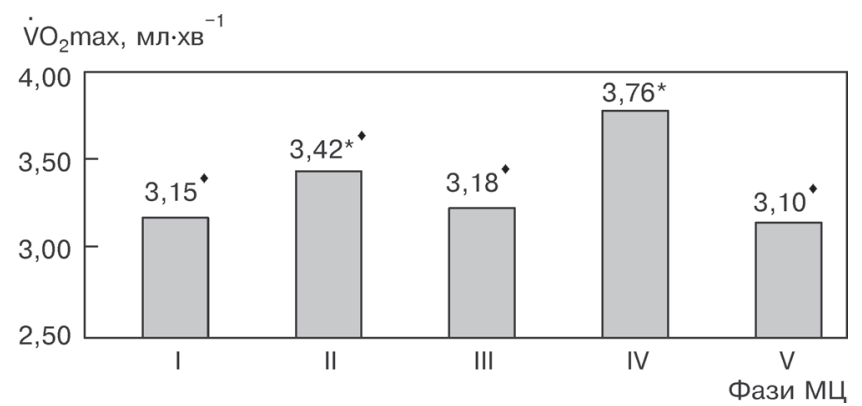

Рисунок 2 - Динаміка максимального споживання кисню у жінок-спортсменок у різні фази МЦ (II розряд)

Примітки. Достовірні зміни результатів: * - порівняно з передменструальною фазою МЦ $(p<0,05) ;{ }^{*}-$ порівняно 3 постовуляторною фазою МЦ $(\mathrm{p}<0,05)$. 
ТАБЛИЦЯ 5 - Показники фізичної працездатності чоловіків у різні мікроцикли

\begin{tabular}{|c|c|c|c|}
\hline \multirow[b]{2}{*}{$\begin{array}{c}\text { Мікро- } \\
\text { циклл }\end{array}$} & \multicolumn{3}{|c|}{ Показник } \\
\hline & маса тіла (кг) & $\begin{array}{c}\text { PWC }_{170}\left(\text { кгм } \cdot \mathbf{x B}^{-1}\right) \\
\text { (абсолютна } \\
\text { величина) }\end{array}$ & $\begin{array}{c}\mathbf{P W C}_{-} \\
\left(\text {кгм } \mathbf{X B}^{-170} \cdot \mathrm{Kr}^{-1}\right) \\
\text { (відносна величина) }\end{array}$ \\
\hline \multicolumn{4}{|c|}{ I розряд, КМС } \\
\hline 1 & $69,18 \pm 5,18$ & $1533,44 \pm 233,74$ & $22,09 \pm 1,95$ \\
\hline II & $69,18 \pm 5,23$ & $1501,91 \pm 345,14$ & $21,58 \pm 3,86$ \\
\hline III & $69,22 \pm 5,31$ & $1576,06 \pm 293,02$ & $22,69 \pm 3,22$ \\
\hline IV & $69,42 \pm 5,16$ & $1450,05 \pm 303,28$ & $20,74 \pm 2,79^{*}$ \\
\hline V & $69,48 \pm 5,05$ & $1428,19 \pm 151,12$ & $20,52 \pm 0,88^{*}$ \\
\hline \multicolumn{4}{|c|}{ II розряд, КМС } \\
\hline I & $65,72 \pm 5,88$ & $1079,30 \pm 162,12$ & $16,62 \pm 3,42$ \\
\hline II & $65,70 \pm 5,95$ & $1177,23 \pm 367,39$ & $18,04 \pm 5,65$ \\
\hline III & $65,78 \pm 5,95$ & $1191,57 \pm 347,48$ & $18,44 \pm 6,20$ \\
\hline IV & $65,80 \pm 5,95$ & $1223,78 \pm 377,63$ & $18,87 \pm 6,34$ \\
\hline V & $65,72 \pm 5,93$ & $1267,21 \pm 224,14$ & $19,54 \pm 4,50$ \\
\hline
\end{tabular}

Примітка. * Достовірні зміни результатів порівняно з ІІІ мікроциклом ( $<<0,05)$.

ших трьох мікроциклів та вірогідно знизилися в четвертому та п'ятому ( $p>0,05$ порівняно 3 третім мікроциклом). У спортсменів II розряду найменший рівень фрізичної працездатності відзначали в першому мікроциклі, його зростання у другому, третьому і у четвертому мікроциклах та максимальні показники - у п'ятому.

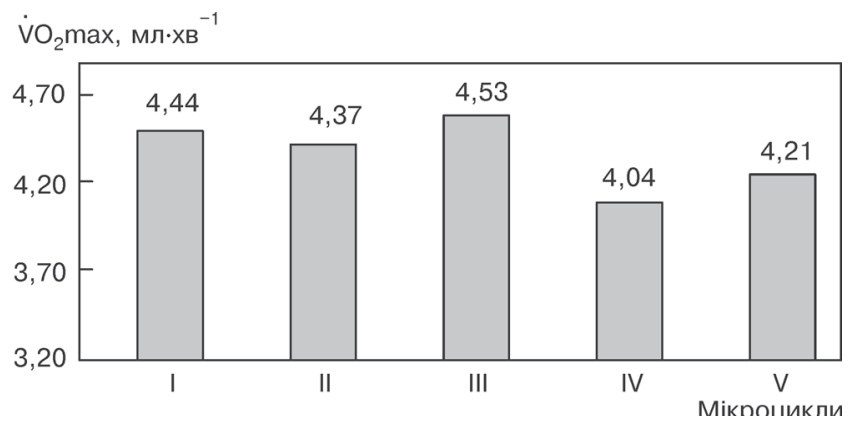

Рисунок 3 - Динаміка максимального споживання кисню базового мезоциклу у різні мікроцикли базового мезоциклу (I розряд, КMC)

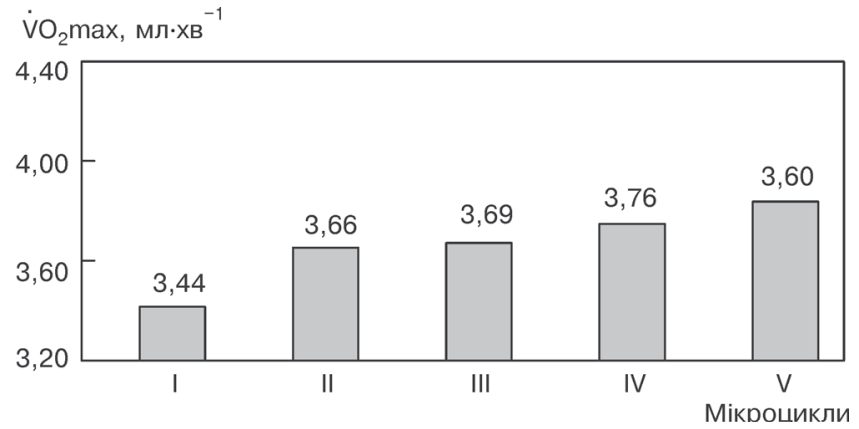

Рисунок 4 - Динаміка максимального споживання кисню у чоловіків-спортсменів у різні мікроцикли базового мезоциклу (II розряд)
Аналізуючи результати фрізичної працездатності $\mathrm{PWC}_{170}$, можемо стверджувати, що спеціальна працездатність у чоловіків залежить від стану кардіореспіраторної системи та, можливо, рівня адаптації спортсменів до тренувальних навантажень.

Результати $\dot{V}_{2} \max$ у чоловіків-спортсменів (I розряд і КМС) (рис. 3), які спеціалізуються в бігу на середні дистанції, свідчать про підвищення доставки кисню до працюючих м'язів у першому й другому мікроциклах $\left(4,44 \pm 0,51\right.$ мл·хв ${ }^{-1}$ і 4,37 $\pm 0,76$ мл·хв ${ }^{-1}$ відповідно), досягаючи свого максимуму в третьому $\left(4,53 \pm 0,64\right.$ мл·хв $\left.{ }^{-1}\right)$. Значне спадання рівня $\dot{V}_{2} \max$ відзначено в чет-

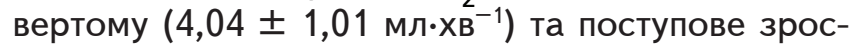
тання - у п'ятому $\left(4,21 \pm 0,33\right.$ мл·хв $\left.{ }^{-1}\right)$ мікроциклах.

Рівень $\dot{\mathrm{VO}}_{2} \max$ у чоловіків-спортсменів II розряду (рис. 4) найнижчий у першому $(3,44 \pm$ $\pm 0,35$ мл·хв $\left.{ }^{-1}\right)$ мікроциклі й поступово зростає в

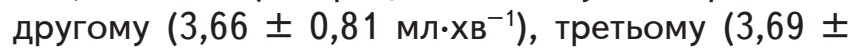
$\pm 0,77$ мл $\left.\times \mathbf{X B}^{-1}\right)$, четвертому $\left(3,76 \pm 0,83 \mathrm{мл \cdot \times B^{-1 } )}\right.$ та найбільше - у п'ятому $\left(3,86 \pm 0,49\right.$ мл·хв $\left.{ }^{-1}\right)$ мікроциклах.

Аналізуючи значення $\mathrm{PWC}_{170}$ та $\dot{\mathrm{VO}}_{2} \max$, можемо стверджувати, що спеціальна працездатність у чоловіків залежить від стану кардіореспіраторної системи й, можливо, рівня їх адаптації до тренувальних навантажень.

Отже, у четвертому мікроциклі зниження функціональних можливостей серцево-судинної системи у чоловіків-спортсменів призводить до зниження спеціальної працездатності та напруженості адаптаційних реакцій на тренувальне навантаження.

Таким чином, нами запропоновано застосовувати три ударні мікроцикли, навантаження яких зростає від значного до великого, та відновлювальний мікроцикл для ефективного перебігу адаптаційних процесів і запобігання перевтомі та перетренуванню. Методологічною основою побудови базових мезоциклів чоловіків-спортсменів слугувало проведене дослідження працездатності та фрункціонального стану їх організму впродовж мезоциклу.

Проведена робота свідчить про те, що спеціальна працездатність та адаптаційні можливості організму легкоатлеток залежать від гормонального статусу протягом МЦ. Нами було запропоновано базовий мезоцикл у спортсменок будувати згідно з функціональними можливостями у різні фази МЦ.

Установлено, що оптимальними для прояву й розвитку якості витривалості $\epsilon$ постовуляторна та 
постменструальна фрази циклу, що підтверджено відмінностями фрункціональних можливостей організму спортсменок у кожній фразі МЦ. Перерозподіл тренувальних навантажень за обсягом й інтенсивністю з урахуванням функціональних можливостей організму спортсменок у різних фразах МЦ уможливить виконання тренером запланованого ним на $100 \%$ навантаження, при цьому збезпечить збереження здоров'я спортсменок, а отже й створення умов для досягнення високих спортивних результатів, збереження спортивного довголіття спортсменів.

Висновки. 1. За результатами аналізу 3'ясовано, що побудову тренувального процесу спортсменів, які спеціалізуються у бігу на середні дистанції, з урахуванням їх функціональних можливостей в теорії та методиці спортивної підготовки належно не відображено. Незначна кількість робіт, у яких наведено аналіз фрізичної та техніко-тактичної підготовки, стосується лише тренування підлітків.

2. Установлено, що функціональний стан і фрізична працездатність упродовж мезоциклу у спортсменів, які спеціалізуються у бігу на середні дистанції, мають різну динаміку: у жінок вони залежать від зміни гормонального статусу протягом менструального циклу; у чоловіків - поступово зростають до настання втоми.

3. Адаптаційні реакції організму жінок, які спеціалізуються в бігу на середні дистанції, до напруженої м'язової діяльності, спрямованої на прояв анаеробної витривалості, характеризуються оптимальним функціональним станом у постовуляторну та постменструальну фрази порівняно із менструальною, овуляторною та передменструальною фразами МЦ. Аналіз варіабельності серцевого ритму, у ході якого виявлено найвищі показники IH у передменструальну фразу, зниження цих показників у менструальну, постменструальну й овуляторну фрази та вірогідно нижчі у постовуляторну ( $<<0,05)$ фразу МЦ, вказує на зниження ступеня напруженості регуляторних систем та підвищення фрункціональних можливостей серцево-судинної системи спортсменок у ці фрази порівняно з передменструальною.

4. Адаптаційні реакції організму чоловіківспорсменів, які спеціалізуються в бігу на середні дистанції, до напруженої м'язової діяльності, спрямованої на прояв анаеробної витривалості, характеризуються оптимальним фрункціональним станом у першому, другому, третьому та п'ятому мікроциклах і незначним його зниженням у четвертому мікроциклі. Вищі показники ІН отримано в перший, другий $(p<0,01, p<0,05)$ та п'ятий (фонова та ортопроба відповідно) мікроцикли та значно нижчі - у третій та четвертий мікроцикли, що свідчить про зниження ступеня напруженості регуляторних систем та підвищення функціональних можливостей серцево-судинної системи спортсменів у цих мікроциклах.

5. Динаміка працездатності у спортсменів, які спеціалізуються в бігу на середні дистанції, у мезоциклі має такі особливості:

а) найвищі показники фрізичної працездатності та $\dot{\mathrm{VO}} 2 \max$ у спортсменок було зафріксовано в постменструальну ( $p<0,05$ порівняно з передменструальною фразою МЦ) та постовуляторну ( $<<0,05)$ фази; значно знижуються в овуляторну ( $<<0,05)$, передменструальну та менструальну $(p<0,05)$ фрази;

в) показники відносної величини PWC $_{170}$ та $\dot{\mathrm{VO}}$ max у чоловіків-спортсменів I розряду та КМС зростали у першому, другому мікроциклі, найвищими були у третьому мікроциклі, знизилися в четвертому мікроциклі ( $<<0,05$ порівняно з третім мікроциклом) і найменшими були у п'ятому мікроциклі порівняно з попередніми мікроциклами ( $<<0,05)$. У спортсменів II розряду найменші рівні фрізичної працездатності та $\mathrm{VO}_{2} \max$ відзначали в першому мікроциклі, зростали вони у другому, дещо вищі - у третьому і четвертому та найбільші - у п'ятому мікроциклі.

6. Результати взаємозв' язку рівня прояву функціональних можливостей спортсменів і ефективності виконання специфічних навантажень мезоциклу стали методологічною основою розробки програм їх тренувальної та змагальної діяльності в мікроциклах і мезоциклах спортивної підготовки. У жінок менструальний цикл різної тривалості можна ототожнити з мезоциклами, складеними 3 мікроциклів із різною переважною спрямованістю. У чоловіків побудова мезоциклу залишається традиційною - три ударні мікроцикли та відновлювальний, відповідно до позитивної адаптації до тренувальних навантажень. 


\section{Література}

1. Баевский Р. М. Вариабельность сердечного ритма: теоретические аспекты и возможности клинического применения / Р. М. Баевский, Г. Г. Иванов // Ультразвуковая и функциональная диагностика. - 2001. № 3. - С. 108-127.

2. Винничук Ю. Д. Механизмы стимуляции фииической работоспособности спортсменов при индуцирующих тканевую гипоксию вибрационных нагрузках / Ю. Д. Винничук, И. А. Лисняк // Спорт. медицина. - 2014. - № 2. - С. 37-45.

3. Калитка С. В. Особливості змін варіабельності серцевого ритму у кваліфікованих спортсменок при адаптації до тренувальних навантажень з бігу на середні дистанції / С. В. Калитка, О. Б. Рода, В. Лавринюк // Спорт. медицина. - 2016. - № 1. - С. 69-76. - Режим доступу : http://nbuv.gov.ua/UJRN/smed_2016_1_10.

4. Лисенко О. М. Тип вегетативної регуляції серцевого ритму і особливості прояву фізичної працездатності кваліфікованих спортсменів / О. М. Лисенко // Вісн. Черкас. ун-ту (Сер. «Біологічні науки»). - 2011. Вип. 204. - С. 100-109.

5. Платонов В. Н. Система подготовки спортсменов в олимпийском спорте. Общая теория и ее практические приложения: учебник [для тренеров]: в 2 кн. - К. : Олимп. лит., 2015. - Т. 2. - 770 с.

6. Рода О. Б. Анализ вариабельности сердечного ритма у женщин, специализирующихся в беге на средние дистанции / О. Б. Рода, С. В. Калитка // Здоровье для всех. - 2014. - № 1. - С. 22-28. Режим доступа : https://cyberleninka.ru/article/n/analiz-variabelnosti-serdechnogo-ritma-u-zhenschin-spetsializiruyuschihsya-v-bege-na-sredniedistantsii.

7. Спортивная медицина : учебник / Л. Я.-Г. Шахлина, Б. Г. Коган, Т. А. Терещенко и др. ; под ред. Л. Я.-Г. Шахлиной. - К. : Наук. думка, 2016. $-452 \mathrm{c}$.

8. Roda O. Heart Rate Variability in Athletes Specializing in MiddleDistance Running during Mesocycle / O. Roda, S. Kalytka, A. Tsos, O. Andriichuk, O. Ishchuk, O. Shvets // Research J. of Pharmaceutical, Biological and Chemical Sciences. - 2017. - Vol. 8 (1). - P. 1061-1070. - Режим доступу : https://www.rjpbcs.com/pdf/2017_8(1)/[133].pdf.

9. Shakhlina L. Physical performance during the menstrual cycle of female athletes who specialize in $800 \mathrm{~m}$ and $1500 \mathrm{~m}$ running / L. Shakhlina, O. Roda, S. Kalytka, O. Romaniuk, N. Matskevych, V. Zakhozhyi // J. of Physical Education and Sport. - 2016. - Vol. 16 (4). - Art 215. - P. 13451351. - Режим доступу : DOI:10.7752/jpes.2016.04215, http://efsupit.ro/ images/stories/nr4.2016/art215.pdf.

\section{References}

1. Baevsky, R.M., Ivanov, G.G. (2001). Variabel'nost' serdechnogo ritma: teoreticheskie aspekty i vozmozhnosti klinicheskogo primeneniya [Heart rate variability: theoretical aspects and possibilities of clinical use]. Ul'trazvukovaya i funktsional'naya diagnostika - Ultrasound and functional diagnostics, 3, 108-127 [in Russian].

2. Vinnichuk, Y.D., Lisnyak. I.A. (2014). Mekhanizmy stimulyacii fizicheskoj rabotosposobnosti sportsmenov pri induciruyushchih tkanevuyu gipoksiyu vibracionnyh nagruzkah [Mechanisms of physical performance stimulation of athletes during tissue hypoxia inducing vibration loads]. Sportivna medicina - Sports medicine, 2, 37-45 [in Russian].

3. Kalytka, S.V., Roda, O.B., Lavryniuk, V. (2016). Osoblyvosti zmin variabelnosti sertsevoho rytmu u kvalifikovanykh sportsmenok pry adaptatsii do trenuvalnykh navantazhen $z$ bihu na seredni dystantsii [Features change of heart rate variability in trained women athletes with adaptation to training loads in middle-distance running]. Sportivna medicina - Sports medicine, 1, 69-76. Retrieved from http://nbuv.gov.ua/UJRN/smed_2016_1_10. [in Ukrainian].

4. Lysenko, O.M. (2011). Typ vehetatyvnoi rehuliatsii sertsevoho rytmu i osoblyvosti proiavu fizychnoi pratsezdatnosti kvalifikovanykh sportsmeniv [Type of autonomic regulation of heart rate and physical performance features of qualified athletes]. Visnyk Cherkaskoho universytetu (Ser. «Biolohichni nauky») - Herald of Cherkasy University (Ser. "Biological Sciences»), Vyp. 204, 100-109 [in Ukrainian].

5. Platonov, V.N. (2015). Sistema podgotovki sportsmenov v olimpijskom sporte. Obshchaya teoriya $i$ ee prakticheskie prilozheniya [The system of training athletes in the Olympic sport. General theory and its practical applications]. Kiev: Olimpiyskaya literatura, Vol. 2, 770 p. [in Russian].

6. Roda, O.B., Kalitka, S.V. (2014). Analiz variabel'nosti serdechnogo ritma $u$ zhenshchin, specializiruyushchihsya $v$ bege na srednie distancii [Analysis of women heart rate variability who specialize in middle-distance running]. Zdorov'ye dlya vsekh - Health for all, 1, 22-28. Retrieved from https://cyberleninka.ru/article/n/analiz-variabelnosti-serdechnogo-rit-/ ma-u-zhenschin-spetsializiruyuschihsya-v-bege-na-srednie-distantsii [in Ukrainian].

7. Shakhlina, L.Ya.-G., Kogan, B.G., Tereschenko, T.A., Tischenko, V.P., Futornyi, S.M. (2016). Sportivnaya meditsina (Sports medicine). L. Ya.-G. Shakhlina (Ed.). Kiev: Nauk. dumka [in Russian].

8. Roda, O., Kalytka, S., Tsos, A., Andriichuk, O., Ishchuk, O., Shvets, O. (2017). Heart Rate Variability in Athletes Specializing in Middle-Distance Running during Mesocycle. Research J. of Pharmaceutical, Biological and Chemical Sciences, Vol. 8 (1), 1061-1070. Retrieved from_https://www. rjpbcs.com/pdf/2017_8(1)/[133].pdf.

9. Shakhlina, L., Roda, O., Kalytka, S., Romaniuk, O., Matskevych, N., Zakhozhyi, V. (2016). Physical performance during the menstrual cycle of female athletes who specialize in $800 \mathrm{~m}$ and $1500 \mathrm{~m}$ running. J. of Physical Education and Sport, Vol. 16 (4), Art 215, 1345-1351. Retrieved from DOI:10.7752/jpes.2016.04215, http://efsupit.ro/images/stories/nr4.2016/ art215.pdf. 